Patrycja Rusiak

Wyższa Szkoła Finansów i Zarządzania w Warszawie

Katedra Psychologii Poznawczej

01-030 Warszawa, ul. Pawia 55

e-mail: patrycja.rusiak@gmail.com

\title{
SKUTECZNOŚĆ PROGRAMU LEARNING BREAKTHROUGH W TERAPII DYSLEKSJI ROZWOJOWEJ
}

\begin{abstract}
Abstrakt. Dysleksja rozwojowa to zaburzenie związane z trudnościami w czytaniu i pisaniu. W literaturze przedmiotu istnieje wiele hipotez mających na celu wyjaśnienie jego przyczyn. Jedną z nich jest teoria deficytu móżdżkowego. Zakłada ona, że głównym czynnikiem utrudniającym proces nauki czytania i pisania są dysfunkcje w budowie oraz funkcjonowaniu móżdżku, czego konsekwencją są deficyty procesu automatyzacji.

Od kilku lat prowadzi się badania zmierzające do stworzenia narzędzi terapeutycznych pomocnych w niwelowaniu trudności obserwowanych u osób dyslektycznych. W chwili obecnej brakuje jednak przekonujących dowodów na temat ich skuteczności. Celem przeprowadzonego badania była ocena efektywności programu terapeutycznego Learning Breakthrough. W tym celu posłużono się czterema testami czytania, które wykonywane były dwukrotnie - przed i po 4-miesięcznym treningu. Oczekiwano poprawy wykonania testów czytania tylko u uczestników z grupy eksperymentalnej. Jednakże analiza statystyczna nie ujawniła żadnych istotnych różnic między wynikami otrzymanymi w preteście i postteście, tak pomiędzy grupą eksperymentalną, jak też i kontrolną. Uzyskane rezultaty sugerują, że interwencja terapeutyczna nie poprawiła poziomu czytania u osób dyslektycznych.
\end{abstract}

Słowa kluczowe: dysleksja rozwojowa, terapia, deficyty móżdżkowe.

\section{WPROWADZENIE}

Dysleksja rozwojowa najczęściej określana jest jako specyficzne zaburzenia w czytaniu i pisaniu. Oznacza to, że odnosi się ona jedynie do tych problemów w czytaniu i pisaniu, które nie są konsekwencją upośledzenia umysłowego, uszkodzenia narządów zmysłu, zaburzeń emocjonalnych i zachowania, a także zaniedbań środowiskowo-kulturowych (Habib, 2000; Shaywitz, 1998). Obecnie uznaje się, że zaburzenie to dotyczy około 5-12\% dzieci w wieku szkolnym (Demb i in., 1997; Shaywitz i in., 1990; Stein, 2004). Badania przeprowadzone w Polsce wśród uczniów klas IV szkół podstawowych pokazały, że 9,2\% (miasto) 
i 10\% (wieś) dzieci cierpi na zaburzenia czytania, natomiast u 13,6\% (miasto) i 16\% (wieś) zdiagnozowano zaburzenia uczenia się poprawnej pisowni (Bogdanowicz, 2003).

Dysleksję rozwojową można rozpatrywać, przyjmując różne punkty widzenia. Spośród wielu teorii próbujących wyjaśnić etiologię oraz patomechanizm tego zaburzenia jedna wydaje się bardzo interesująca. Jest to koncepcja deficytów móżdżkowych (Fawcett, Nicolson, 2004; Nicolson, Fawcett, 1995; Nicolson i in., 2001). Zakłada ona, że przyczyną trudności obserwowanych u osób dyslektycznych są zaburzenia w budowie oraz funkcjonowaniu móżdżku (Rae i in., 1998, 2002). Według przedstawicieli tego podejścia, móżdżek odpowiedzialny jest zarówno za problemy językowe, jak i trudności w utrzymywaniu równowagi, koordynacji wzrokowo-ruchowej, a także wykrywanie i uczenie się sekwencji określonych bodźców. Badacze wykazali, że źródeł tych trudności należy upatrywać w deficytach procesu nabywania nowych umiejętności i ich automatyzacji, za którego prawidłowy przebieg odpowiedzialny jest właśnie móżdżek (Ito, 1990; Jenkins i in., 1994).

\section{FUNKCJE MÓŻDŻKU}

Mimo swojego niepozornego wyglądu, móżdżek zawiera około $10^{11}$ neuronów, co stanowi 50\% neuronów całego mózgu. Otrzymuje i wysyła informacje do wielu obszarów mózgu, między innymi rdzenia kręgowego, rdzenia przedłużonego, pnia mózgu, kory mózgowej, układu limbicznego oraz jąder podstawnych kresomózgowia (Fawcett, Nicolson, 2004; Longstaff, 2002). Początkowo sądzono (Fix, 1997), że móżdżek pełni trzy zasadnicze funkcje: utrzymuje postawę i równowagę ciała, utrzymuje napięcie mięśniowe oraz koordynuje świadomą aktywność ruchową (bierze udział w nabywaniu i wykonywaniu czynności ruchowych). Ostatnie badania rozszerzyły udział ,tylnego mózgu” w funkcjach poznawczych (Molinari i in., 1997; Schmahmann, 2002). Okazało się, że zaburzenia pracy móżdżku w istotny sposób wpływają na przetwarzanie językowe, spostrzeganie i rozpoznawanie kolejności zdarzeń, myślenie abstrakcyjne oraz nabywanie i automatyzację nowych umiejętności poznawczych (Ito, 1990; Jenkins i in., 1994). Wiadomo także, że w móżdżku zachodzi integracja informacji zmysłowych, dzięki której możliwe jest przewidywanie skutków działań oraz ich regulowanie i automatyzacja. Ostatnie badania ujawniły, że automatyzacja dotyczy nie tylko czynności ruchowych, ale również tych związanych z mową. Leiner i in. (1991, 1993) uważają, że dzięki licznym połączeniom z korą czołową, gdzie między innymi znajduje się obszar mowy Broca, móżdżek zaangażowany jest w nabywanie sprawności językowych oraz wykonywanie zadań związanych z przetwarzaniem fonologicznym i semantycznym (Ackerman, Cianciolo, 2000; Fabbro, 2000; Fulbright i in., 1999; Silveri $\mathrm{i}$ in., 2000). 


\section{ROLA MÓŻDŻKU W PROCESACH AUTOMATYZACJI CZYNNOŚCI}

Automatyzacja jest procesem, przez który dobrze wyuczone umiejętności stają się coraz płynniejsze i zachodzą bez udziału naszej świadomości. Są dwa warunki przetwarzania automatycznego: szybkość i mała ilość świadomego wysiłku lub jego całkowity brak. Za nabywanie i automatyzację (czyli uwewnętrznianie) czynności odpowiedzialny jest móżdżek. Umożliwia on przesunięcie nabywanych umiejętności poza świadomą kontrolę, przez co są one wykonywane sprawniej, bez świadomego wysiłku. Jednak móżdżek nigdy nie pracuje sam. Na skutek licznych połączeń z różnymi obszarami mózgu (korowe obszary zmysłowe, korowe obszary ruchowe, obszary podkorowe, np. jądra podstawy) pomaga on w uwewnętrznianiu (czyli automatyzowaniu) ruchów, czynności oraz myśli (Fawcett i in., 1996; Fawcett, Nicolson, 2004).

Czytanie jest umiejętnością bardzo złożoną, na którą składają się dwa podstawowe procesy - dekodowanie, które wiąże się ze zdolnością manipulowania dźwiękami mowy (poprawne łączenie fonemu z odpowiadającym mu grafemem), oraz rozumienie. Im sprawniejsze staje się dekodowanie, im mniej wysiłku inwestujemy, tym więcej uwagi może zostać skierowane na rozumienie czytanej treści. Aby zatem czytanie przebiegało płynnie i szybko, wymagana jest automatyzacja procesów, które się na nie składają. Istotną rolę móżdżku w procesie czytania ujawnili Fulbright i współpracownicy (1999). Wykazali oni, że podczas czytania móżdżek ulega aktywacji, a w szczególności jego środkowa i tylna część - tylna górna bruzda, płacik prosty oraz półksiężycowaty. W przetwarzanie semantyczne zaangażowane są głębiej leżące obszary jąder zlokalizowane po prawej stronie oraz dolne części robaka móżdżku. Zadania fonologiczne natomiast aktywują tylne obszary łącznie z płacikiem prostym oraz górnym i dolnym obszarem płacika półksiężycowatego. Turkeltauba i in. (2002) wykazali, że głośne czytanie pojedynczych słów pobudza obustronnie obszar ruchowy i górną okolicę skroniową, okolicę przedruchową, lewy zakręt wrzecionowaty i móżdżek. Badania Jobarda $i$ in. (2003), za pomocą metody neuroobrazowania, potwierdziły znaczną aktywację móżdżku podczas czytania.

\section{AUTOMATYZACJA CZYNNOŚCI U OSÓB DYSLEKTYCZNYCH}

Brak automatyzacji czynności, zarówno ruchowych, jak i poznawczych, w tym czytania, u osób z dysleksją rozwojową związany jest z brakiem aktywacji móżdżku podczas tych czynności (Fawcett, Nicolson; 2004). Według Nicolsona i in. (2001) podstawowym ogniwem łączącym zaburzenia w obrębie móżdżku i niepowodzenia w czytaniu jest artykulacja mowy. Zaburzenia móżdżkowe powodują nieprawidłowości mowy, które to przyczyniają się do problemów w rozumieniu mowy (czyli ze słyszeniem dźwięków mowy). To z kolei powoduje 
zaburzenia w rozwoju świadomości fonologicznej (tzn. brak umiejętności w posługiwaniu się, manipulowaniu fonemami), a jak wiadomo, świadomość fonologiczna jest niezbędna do nauki czytania. Zaburzenia móżdżku wyjaśniają również w sposób bezpośredni niestaranne pismo (dysgrafia) u osób z dysleksją rozwojową. Pisanie jest bowiem czynnością ruchową, która wymaga koordynacji różnych grup mięśni, a za to właśnie odpowiada móżdżek (Fawcett, Nicolson, 2004).

\section{ZABURZENIA STRUKTURY MÓŻDŻKU U OSÓB DYSLEKTYCZNYCH}

Badania przeprowadzone wśród osób z dysleksją rozwojową pokazały istotne zaburzenia w strukturze móżdżku (Eckert i in., 2003; Finch i in., 2002; Rae i in., 1998, 2002). Rae i jej współpracownicy $(1998,2002)$ wykazali, iż w móżdżkach osób z dysleksją występują zmiany morfologiczne, jak i metaboliczne. Zmiany biochemiczne zaobserwowano w lewym obszarze skroniowo-ciemieniowym oraz w prawej części móżdżku. Dodatkowo ujawniono, że w lewej części kory móżdżku stosunek grubości warstwy szarej do białej jest większy w grupie dyslektycznej niż w grupie kontrolnej (Rae i in., 1998). W wyniku przeprowadzonych badań morfologicznych móżdżku (Rae i in., 2002) osób z udokumentowaną nieumiejętnością czytania okazało się, że występuje u nich atypowa asymetria istoty szarej móżdżku, której nie zaobserwowano u osób z grupy kontrolnej, u których prawa część tego obszaru mózgu jest większa niż lewa (odwrotnie niż na poziomie kory mózgowej, gdzie obserwuje się przewagę półkuli lewej nad prawą). Co więcej, badacze doszli do wniosku, że stopień symetrii móżdżku wiąże się z poziomem deficytu dekodowania fonologicznego. Osoby z prawie symetrycznym móżdżkiem były wolniejsze i robiły więcej błędów w pomiarach zdolności dekodowania fonologicznego mierzonego testem czytania pseudowyrazów.

W wyniku przeprowadzonych badań neuroanatomicznych, Finch i in. (2002) wykazali znaczne anomalie w budowie komórek i ich położeniu w móżdżku u osób $\mathrm{z}$ dysleksją. Zaobserwowali istnienie większych komórek w tej strukturze mózgowej, szczególnie w jego przednim płacie oraz w dolnym jądrze oliwki leżącym w obrębie pnia mózgu, którego zadaniem jest przesyłanie informacji do móżdżku.

Również badania przeprowadzone przy użyciu MRI wśród osób z dysleksją ujawniły zaburzenia w obrębie móżdżku. Okazało się, że obserwowane u osób słabo czytających trudności w czytaniu korelują ze zmniejszonym obrębem prawego płata przedniego móżdżku i obustronnym zmniejszeniem części trójkątnej w płacie czołowym mózgu, który odpowiada za generowanie mowy. Anomalie w tych obszarach odróżniały mózgi osób z dysleksją od grupy kontrolnej (Eckert i in., 2003).

Rezultaty badań dotyczących struktury móżdżku potwierdzają nieprawidłowości występujące w tym obszarze u osób z dysleksją rozwojową i tym samym dają dowody na słuszność hipotezy deficytu móżdżkowego. 


\section{TERAPIA DYSLEKSJI ROZWOJOWEJ}

W literaturze przedmiotu można znaleźć informacje na temat różnych form pomocy osobom dyslektycznym. Większość z proponowanych programów bazuje na koncepcji zaburzeń świadomości fonologicznej. Pierwszymi, którzy wykorzystali wiedzę pochodzącą z badań opartych na koncepcji deficytów móżdżkowych (Nicolson, Fawcett, 1990) w skonstruowaniu programu pomocy dla osób dyslektycznych, byli Dore i Rutheford (2001). Przyjęli oni założenie o tym, że w okresie dzieciństwa móżdżek jest plastyczny, przez co istnieje prawdopodobieństwo „wytrenowania” tego obszaru poprzez wykonywanie odpowiednich ćwiczeń (rehabilitacja motoryczna). Bazując na doniesieniach naukowych, stworzyli specjalny program terapeutyczny, który nazwali Balance Remediation Exercise Training. Zadaniem uczestnika treningu jest wykonywanie określonych ćwiczeń motorycznych -2 razy dziennie po 10 minut przez okres kilku miesięcy. Udział w programie jest dość kosztowny, bo wynosi około 4000 \$ (Pennington, 2008). Skuteczność programu została zweryfikowana w 2003 roku przez zespół pod kierownictwem Reynoldsa (Reynolds i in., 2003). Okazało się, że 6-miesięczny trening istotnie wpłynął nie tylko na polepszenie funkcji motorycznych (zdolność utrzymywania równowagi, sprawność manualną), ale także funkcji językowych (zdolności fonologiczne, płynność fonetyczną i semantyczną, płynność czytania wyrazów prawdziwych i bezsensownych). Kolejne badanie przeprowadzone przez ten sam zespół badawczy (Reynolds, Nicolson, 2007) ujawniło, tak jak poprzednio, że po 6 miesiącach treningu dzieci dyslektyczne uzyskały poprawę wyników w testach badających płynność semantyczną, szybkość nazywania, umiejętności fonologiczne, a także zdolność pisania i rozumowania. Ponadto okazało się, że w grupie dzieci biorących udział w treningu nastąpiła znaczna poprawa wykonania zadań wymagających skupiania uwagi. Otrzymane rezultaty powtórzono po kolejnych 6 miesiącach i ponownie zaobserwowano istotną poprawę w obszarze językowym u dzieci biorących udział w programie terapeutycznym.

Badania te spotkały się z liczną krytyką środowiska naukowego (Pennington, 2008; Rack i in., 2007; Snowling i Hulme, 2003). Po pierwsze dlatego, że wspomniany program jest programem komercyjnym, przez co trudno poddać go obiektywnej, naukowej ocenie. Dodatkowo badacze, którzy przeprowadzili weryfikację skuteczności programu, należeli do grupy, która ów program stworzyła. Trudno zatem uznać otrzymane wyniki za niezależne. Z krytyką spotkała się również sama metoda przeprowadzonych badań. Wskazano liczne uchybienia metodologiczne, takie jak niewłaściwy dobór osób do grupy badanej (tylko 6 uczestników miało zdiagnozowaną dysleksję rozwojową, 2 uczestników cierpiało na dyspraksję, a 1 z nich na ADHD), czy brak grupy kontrolnej.

Innym programem terapeutycznym skonstruowanym w oparciu o koncepcję deficytów móżdżkowych jest program Learning Breakthrough. Jak czytamy na stronie internetowej, program bazuje na założeniu, że funkcje motoryczne i sensoryczne są ze sobą mocno powiązane. Głównym celem proponowanych ćwiczeń 
jest wzmocnienie neurotransmisji w mózgu prowadzące do lepszej współpracy jego poszczególnych obszarów, a w konsekwencji do polepszenia ogólnego funkcjonowania poznawczego człowieka, w tym czytania. Program składa się z kilkunastu ćwiczeń wzrokowo-motorycznych wykonywanych przy pomocy różnych przyrządów, takich jak równoważnia, kolorowy drążek, piłka zawieszona na sznurku, stojak, woreczki wypełnione fasolą oraz drewniana tablica numeryczna wraz z czterema piłkami kauczukowymi.

Zdaniem twórców programu, jego skuteczność zależy od częstotliwości i powtarzalności treningu. W zaleceniach czytamy, że optymalny czas ćwiczeń to dwukrotne powtórzenie w ciągu dnia serii przygotowanych zadań, 5 minut rano i 15 minut po południu lub wieczorem (najlepiej tuż przed odrabianiem lekcji). Wykonywanie czynności więcej niż dwa razy każdego dnia nie jest zalecane. Czas trwania programu jest realizowany według zasady „im dłużej tym lepiej”, jednak zazwyczaj nie trwa dłużej niż 12 miesięcy. W zależności od zaangażowania i potencjału neurologicznego uczestnika pierwsze efekty powinny być zauważalne już po 3 miesiącach od rozpoczęcia treningu.

Program Learning Breakthrough jest również programem komercyjnym, jednak jego koszta są zdecydowanie niższe niż opisanego powyżej programu DORE. Na swojej stronie autorzy programu donoszą o jego skuteczności. Jednak stwierdzenia te nie zostały potwierdzone żadnymi badaniami naukowymi. Doniesienia o efektywności oparte są wyłącznie na relacjach samych uczestników programu. $\mathrm{Z}$ tego powodu, aby oszacować skuteczność proponowanego programu, postanowiono wykorzystać przygotowany scenariusz terapeutyczny w pracy z dziećmi z dysleksją z ostatnich klas szkoły podstawowej (V i VI). Gdyby okazało się, że odpowiednio przygotowane ćwiczenia wzrokowo-ruchowe pozytywnie wpływają na poprawę umiejętności czytania, to można byłoby wykorzystać je w pracy z dziećmi dyslektycznymi już na bardzo wczesnym etapie nauki szkolnej.

\section{CEL BADANIA}

Celem przeprowadzonych badań była próba weryfikacji skuteczności programu terapeutycznego Learning Breakthrough, stworzonego w oparciu o teorię deficytów móżdżkowych. Program polega na wykonywaniu ćwiczeń ruchowych rozpisanych na każdy dzień planowanego treningu. Efektywność programu terapeutycznego oceniana była za pomocą przeprowadzonych testów czytania.

\section{UCZESTNICY BADANIA}

W badaniu wzięło udział 32 dzieci z klas V i VI szkoły podstawowej. Wszystkie dzieci posiadały opinię o dysleksji rozwojowej wydaną przez uprawnioną do tego placówkę oświatową. Dzieci w sposób losowy zostały przydzielone do grupy 
eksperymentalnej (16 dzieci, 6 dziewczynek i 10 chłopców) i kontrolnej (16 dzieci, 8 dziewczynek i 8 chłopców). Każde z dzieci, niezależnie od przynależności do grupy, dwukrotnie wykonywało cztery testy mające na celu określić poziom umiejętności czytania (pretest i posttest). Do udziału w 4-miesięcznym treningu terapeutycznym zaproszone zostały tylko dzieci z grupy eksperymentalnej. Badania zostały przeprowadzone w roku szkolnym 2012/2013 i 2013/2014.

\section{NARZĘDZIA I PROCEDURA BADAWCZA}

Badanie zostało podzielone na trzy części. Pierwsza (pretest) oraz trzecia (posttest) zostały przeprowadzone w celu określenia poziomu umiejętności czytania uczestników. W tym celu posłużono się czterema testami, takimi jak test słów i zdań łańcuchowych oraz test tempa czytania wyrazów prawdziwych i sztucznych. W drugiej części badania - treningowej, wzięły udział wyłącznie dzieci z grupy eksperymentalnej. Wszystkie przeprowadzone badania miały charakter indywidualny i odbywały się na terenie szkoły, w której zaproszone do badań dzieci uczyły się.

\section{TESTY CZYTANIA}

Test łańcuchowy opracowany został przez J. Obera, E. Jaśkowską, P. Jaśkowskiego i J. J. Obera (1998). Składa się on z dwóch części: testu słów łańcuchowych i testu zdań łańcuchowych. Pierwszy z nich pozwala oszacować zdolność dekodowania pojedynczych wyrazów. Natomiast drugi pozwala ocenić poziom rozumienia czytanego tekstu. W badaniu wykorzystano trzy z dwudziestu tablic z każdego testu. Pierwsza tablica traktowana była jako etap próbny, natomiast kolejne dwie stanowiły właściwą część eksperymentu. Słowa łańcuchowe oznaczają dwa słowa (rzeczowniki) napisane łącznie, np. krzesłozupa. Zdania łańcuchowe to ciąg zdań, które nie są rozdzielone kropką ani nie zaczynają się od wielkiej litery. Zadaniem uczestnika badania było rozdzielić pionową kreską słowa łańcuchowe i zdania łańcuchowe. Dla każdej tablicy mierzony był czas wykonania zadania (w sekundach) oraz liczba popełnionych błędów. Za błąd uznawano brak, niepoprawne lub niejednoznaczne rozdzielenie wyrazów czy zdań.

Test tempa czytania wyrazów jest testem służącym do oceny umiejętności i tempa czytania wyrazów znanych (część pierwsza) i sztucznych (część druga). Test został opracowany przez M. Szczerbińskiego. Pierwszy test (test tempa czytania wyrazów znanych) wykorzystany był do określenia poprawności i szybkości czytania wyrazów, które występują z dużą częstotliwością w języku polskim. Składał się on z trzech tablic, z których pierwsza pozwalała badanemu zapoznać się z charakterem zadania (etap próbny), natomiast kolejne dwie tablice 
stanowiły właściwą część badania. Zadaniem badanego było przeczytać na głos kolejne wyrazy (cały test składał się z 75 wyrazów). Mierzono liczbę poprawnie przeczytanych wyrazów w ciągu 60 sekund. Test tempa czytania wyrazów sztucznych pozwalał ocenić poprawność i tempo czytania pseudowyrazów, czyli wyrazów zmyślonych, które nie występują w języku polskim, choć brzmieniem je przypominają, np. skorpytka albo łacierka. Aby prawidłowo wykonać to zadanie, nie należało posługiwać się strategią czytania całych wyrazów (nie można wykorzystać wpływu skojarzeń związanych ze znaczeniem słów w celu szybszego wykonania testu), ale właściwie dopasowywać fonemy do odpowiadających im grafemów. Test ten również składał się z 3 tablic. Tak jak poprzednio, pierwsza tablica pozwalała badanemu zapoznać się ze specyfiką badania. Kolejne dwie tablice składały się na właściwą część badania, a uzyskane z nich wyniki brane były pod uwagę w dalszej analizie. Zadaniem osoby badanej było przeczytanie na głos (szybko i poprawnie) kolejnych pseudowyrazów ułożonych w 3 kolumnach (po 23 wyrazy sztuczne w każdej). Czas wykonania zadania wynosił 60 sekund na jedną tablicę.

\section{OPIS NARZĘDZIA I PRZEBIEGU PROGRAMU TERAPEUTYCZNEGO LEARNING BREAKTHROUGH}

Program terapeutyczny składał się z ćwiczeń wzrokowo-ruchowych wykonywanych indywidualnie przez uczestników badania każdego dnia przez okres 4 miesięcy (16 tygodni). Ćwiczenia zmieniały się codziennie, od poniedziałku do piątku, przez pierwsze 8 tygodni zestaw 1, a w kolejnych tygodniach (od 9 do 16 tygodnia) - zestaw 2. Dzieci wykonywały wszystkie ćwiczenia stojąc na specjalnej równoważni. Poziom trudności balansowania ciałem dostosowywany był indywidualnie do możliwości każdego uczestnika i stopniowo (w kolejnych tygodniach) zwiększany. Zajęcia odbywały się codziennie, od poniedziałku do piątku i trwały każdorazowo 20-25 minut. Zadaniem badanych było m.in.: (1) podrzucać woreczki wypełnione fasolą w określonej sekwencji, jedną ręką lub obiema rękami; (2) odbijanie piłeczki zawieszonej pod sufitem opuszkami palców, pięścią, bokiem ręki (w określonej sekwencji); (3) odbijanie piłeczki zawieszonej pod sufitem specjalnym drewnianym drążkiem (w określonej sekwencji); (4) odbijanie piłeczki zawieszonej pod sufitem całą długością ręki (bark, łokieć, nadgarstek, dłoń itd.); (5) odbijanie piłeczki zawieszonej pod sufitem czołem, nosem, brodą; (6) odbijanie piłeczki zawieszonej pod sufitem zgodnie ze wzorem podanym przez eksperymentatora, tzn. tak aby piłeczka poruszała się nad określonymi obiektami ustawionymi na specjalnym stojaku; (7) rzucanie piłeczką lub piłeczkami kauczukowymi w określone miejsce na drewnianej, numerycznej tablicy ustawionej na podłodze. 


\section{WYNIKI}

Analiza statystyczna przeprowadzona została przy użyciu analizy wariancji: rodzaj testu (pretest $v s$ posttest) x przynależność do grupy (eksperymentalna vs kontrolna). Okazało się, że dla zmiennej czas (Test słów łańcuchowych i Test zdań łańcuchowych) i tempo (Test wyrazów znanych i Test wyrazów sztucznych) czytania, osoby z grupy eksperymentalnej i kontrolnej wykonywały testy czytania równie szybko. Nie ujawniono różnic istotnych statystycznie dla zmiennej przynależność do grupy zarówno dla Testu słów łańcuchowych $(p>0,05)$, Testu zdań łańcuchowych $(p>0,05)$, Testu wyrazów znanych $(p>0,05)$ oraz Testu wyrazów sztucznych $(p>0,05)$. Ważnym czynnikiem wpływającym na czas i tempo wykonania testów czytania była zmienna rodzaj testu (pretest $v s$ posttest). Uczestnicy badania czytali szybciej oraz zwiększyli tempo czytania w postteście w porównaniu z wynikami uzyskanymi w preteście we wszystkich przeprowadzonych te$\operatorname{stach}($ tab. 1).

Tabela 1. Wyniki testów czytania (czas - mierzony w sekundach i tempo - mierzone liczbą poprawnie przeczytanych wyrazów) dla zmiennej rodzaj testu (pretest vs posttest)

\begin{tabular}{|l|c|c|c|c|}
\hline \multirow{3}{*}{ Rodzaj testu } & \multicolumn{4}{|c|}{ Testy czytania } \\
\cline { 2 - 5 } & $\begin{array}{c}\text { Wyrazy prawdziwe } \\
\text { (liczba) } \\
\text { [odchylenie } \\
\text { standardowe] }\end{array}$ & $\begin{array}{c}\text { Wyrazy sztuczne } \\
\text { (liczba) } \\
\text { [odchylenie } \\
\text { standardowe] }\end{array}$ & $\begin{array}{c}\text { Słowa łańcuchowe } \\
\text { (s) } \\
\text { [odchylenie } \\
\text { standardowe] }\end{array}$ & $\begin{array}{c}\text { Zdania łańcuchowe } \\
\text { (s) } \\
\text { [odchylenie } \\
\text { standardowe] }\end{array}$ \\
\hline Pretest & 42,97 & 24,97 & 299,14 & 257,25 \\
Posttest & {$[17,12]$} & {$[9,71]$} & {$[119,82]$} & {$[158,57]$} \\
\hline
\end{tabular}

Źródło: opracowanie własne.

Tabela 2. Średnia liczba przeczytanych wyrazów w Teście wyrazów znanych w preteście i postteście dla zmiennej przynależność do grupy (eksperymentalna vs kontrolna)

\begin{tabular}{|l|c|c|}
\hline \multirow{2}{*}{\begin{tabular}{c}
\multirow{2}{*}{$\begin{array}{c}\text { Przynależność } \\
\text { do grupy }\end{array}$} \\
\cline { 2 - 3 }
\end{tabular}} & $\begin{array}{c}|c| \\
\text { Test wyrazów znanych } \\
\text { (liczba) }\end{array}$ \\
\hline \multirow{2}{*}{ Eksperymentalna } & $\begin{array}{c}\text { Pretest } \\
\text { [odchylenie standardowe] }\end{array}$ & $\begin{array}{c}\text { Posttest } \\
\text { [odchylenie standardowe] }\end{array}$ \\
\hline Kontrolna & 40,37 & 48,00 \\
& {$[17,36]$} & {$[16,94]$} \\
\hline
\end{tabular}

Źródło: opracowanie własne. 
Interakcja między zmiennymi (rodzaj testu x przynależność do grupy) okazała się istotna wyłącznie dla Testu wyrazów znanych $(\mathrm{F}(1,30)=62,02 ; \mathrm{p}<0,05)$. Zarówno osoby z grupy eksperymentalnej, jak i kontrolnej przeczytały więcej wyrazów $\mathrm{w}$ postteście $\mathrm{w}$ porównaniu $\mathrm{z}$ wynikiem otrzymanym $\mathrm{w}$ preteście, jednak dla osób z grupy eksperymentalnej poprawa wyniku okazała się większa (tab. 2). Dla pozostałych testów czytania (Test wyrazów sztucznych, Test słów łańcuchowych, Test zdań łańcuchowych) interakcja między zmiennymi okazała się nieistotna na poziomie statystycznym $(\mathrm{p}>0,05)$.

Analiza wariancji przeprowadzona dla poprawności wykonania testu słów i zdań łańcuchowych ujawniła, że uczestnicy z obu grup uzyskali zbliżone wyniki ( $\mathrm{p}>0,05) . \mathrm{W}$ Teście słów łańcuchowych zmienna rodzaj testu (pretest $v s$ posttest) okazała się nieistotna statystycznie ( $\mathrm{p}>0,05)$, inaczej niż w Teście zdań łańcuchowych $(\mathrm{p}<0,05)$, w którym uczestnicy badania w preteście $(13,12)$ popełniali więcej błędów niż w postteście $(8,71)$. Interakcja między zmiennymi okazała się nieistotna statystycznie $(\mathrm{p}>0,05)$.

\section{DYSKUSJA}

Problem dysleksji rozwojowej od wielu lat jest powszechnym zjawiskiem w polskich szkołach. Pomimo że od lat prowadzone są badania dotyczące tego tematu, wciąż brakuje skutecznych i potwierdzonych naukowo metod interwencji terapeutycznych, które pozwoliłyby na wyeliminowanie lub choćby częściową poprawę funkcjonowania dziecka w obszarze językowym. Trzeba zdawać sobie sprawę z tego, iż brak właściwego i wczesnego oddziaływania terapeutycznego u dzieci z dysleksją rozwojową może przyczynić się do trudności obserwowanych na wszystkich etapach edukacji szkolnej (język polski, języki obce, matematyka, geografia itd.), a często nawet może stać się poważną przeszkodą w budowaniu właściwych relacji z innymi ludźmi. W konsekwencji brak wczesnej diagnostyki oraz brak odpowiednich oddziaływań mogących wyrównać ewentualne trudności może przyczynić się do gorszego startu dziecka w dorosłe życie. W tym celu przeprowadzono badanie mające na celu zweryfikowanie efektywności programu terapeutycznego stworzonego w oparciu o teorię deficytów móżdżkowych. Gdyby okazało się, że udział osób z dysleksją w 4-miesięcznym treningu istotnie poprawia ich umiejętność czytania, to można by wyposażyć placówki zajmujące się pomocą dzieciom $\mathrm{z}$ trudnościami w nauce $\mathrm{w}$ dodatkowe narzędzie terapeutyczne.

Analiza otrzymanych wyników testów czytania ujawniła brak oczekiwanych rezultatów dla Testu słów i zdań łańcuchowych oraz Testu wyrazów sztucznych. Okazało się, że niezależnie od udziału w programie terapeutycznym nie nastąpiła statystycznie istotna poprawa w poziomie wykonania wymienionych testów, zarówno w czasie, jak i w tempie czytania oraz liczbie popełnianych błędów. Inną zależność zaobserwowano dla Testu wyrazów znanych. Okazało się, że zarówno 
osoby z grupy eksperymentalnej, jak i kontrolnej przeczytały więcej wyrazów w postteście $\mathrm{w}$ porównaniu $\mathrm{z}$ wynikiem otrzymanym w preteście, jednak dla osób z grupy eksperymentalnej poprawa wyniku okazała się większa. Oznacza to, że udział w programie terapeutycznym ma ograniczony wpływ na poprawę jakości czytania. Zakładano bowiem, za twórcami programu terapeutycznego Learning Breakthrough, że osoby z grupy eksperymentalnej po 4-miesięcznym treningu będą wykonywały testy czytania lepiej niż ich rówieśnicy z grupy kontrolnej, tzn. poprawa wyników zostanie odnotowana dla wszystkich przeprowadzonych testów. Tak jednak się nie stało. Brak wyraźnej poprawy umiejętności czytania mierzonej czasem i tempem czytania oraz liczbą popełnianych błędów może wynikać z pewnych ograniczeń w samej procedurze przeprowadzonego treningu terapeutycznego. Można założyć, że wydłużenie czasu trwania samego programu powyżej 4 miesięcy, a także rozbudowanie ćwiczeń o dodatkowe zadania wpływające na koordynację wzrokowo-ruchową, a tym samym na funkcje móżdżkowe, może przyczynić się do zwiększenia poprawy w testach czytania. Gdyby tak się stało, można byłoby rozszerzyć formę pomocy udzielanej dzieciom z dysleksją rozwojową.

\section{BIBLIOGRAFIA}

Ackerman P. L., Cianciolo A. T. (2000). Cognitive, perceptual speed, and psychomotor determinants of individual differences during skill acquisition. Journal of Experimental Psychology: Applied, 6, 259-290

Bogdanowicz M. (2003). Longitudinalne badania nad dysleksją rozwojową w Polsce. W: B. Wojciszke, M. Plopa (red.), Osobowość a procesy psychiczne i zachowanie (s. 357-383). Kraków: Oficyna Wydawnicza Impuls

Demb J. B., Boynton G. M., Heeger D. J. (1997). Brain activation in visual cortex predicts individual differences in reading performance. Proceedings of the Natural Academic Sciences, 94, 13363-13366

Dore W., Rutherford R. (2001). Closing the gap. Paper presented at the BDA $6^{\text {th }}$ International Conference on Dyslexia, York, UK

Eckert M. A., Leonard C. M., Richards T. L., Aylward E. H., Thomson J., Berninger V. W. (2003). Anatomical correlates of dyslexia: Frontal and cerebellar findings. Brain: A Journal of Neuro$\log y, 126$ (2), 482-494

Fabbro F. (2001). The bilingual brain: Cerebral representation of languages. Brain Lang., 79 (2), $211-222$

Fawcett A. J., Nicolson R. I., Dean P. (1996). Impaired performance of children with dyslexia on a range of cerebellar tasks. Ann Dyslexia, 46, 259-283

Fawcett A. J., Nicolson R. I. (2004). Rola móżdżku w dysleksji. W: A. Grabowska, K. Rymarczyk (red.), Dysleksja od badań mózgu do praktyki (s. 43-75). Warszawa: Instytut Biologii Doświadczalnej im. M. Nenckiego PAN

Finch A. J., Nicolson R. I., Fawcett A. J. (2002). Evidence for a neuroanatomical difference within the olivo-cerebellar pathway of adults with dyslexia. Cortex, 38, 529-539

Fix J. D. (1997). Neuroanatomia. Wrocław: Urban \& Partner. Wydawnictwo Medyczne

Fulbright R. K., Jenner A. R., Mencl W. E., Pugh K. R., Shaywitz B. A., Shaywitz S. E., Frost S. J., Skudlarski P., Constable R. T., Lacadie C. M., Marchione K. E., Gore J. C. (1999). The cerebellum's role in reading. American Journal of Neuroradiology, 20, 1925-1930 
Habib M. (2000). The neurological basis of developmental dyslexia: An overview and working hypothesis. Brain, 123, 2373-2399

Ito M. (1990). A new physiological concept on cerebellum. Journal of Cognitive Neuroscience, 1, $136-152$

Jenkins T. C., Abd-Manan F., Pardhan S., Murgatroyd R. N. (1994). Effect of fixation disparity on distance binocular visual acuity. Ophthalmic Physiol. Opt., 14 (2), 129-131

Jobard G., Crivello F., Tzourio-Mazoyer N. (2003). Evaluation of the dual route theory of reading: A metanalysis of 35 neuroimaging studies. Neuroimage, 20 (2), 693-712

Leiner H. C., Leiner A. L., Dow R. S. (1991). The human cerebro-cerebellar system: Its computing, cognitive, and language skills. Behav. Brain Res., 44 (2), 113-128

Leiner H. C., Leiner A. L., Dow R. S. (1993). Cognitive and language functions of the human cerebellum. Trends Neuroscience, 16 (11), 444-447

Longstaff A. (2002). Neurobiologia. Krótkie wyktady. Warszawa: Wydawnictwo Naukowe PWN

Molinari M., Leggio M. G., Solida A., Ciorra R., Misciagna S., Silveri M., Petrosini L. (1997). Cerebellum and procedural learning: Evidence from focal cerebellar lesions. Brain, 120, 1753-1762

Nicolson R. I., Fawcett A. J. (1990). Automaticity: A new frame work for dyslexia research? Cognition, 35, 159-182

Nicolson R. I., Fawcett A. J. (1994). Comparison of deficits in cognitive and motor skills among children with dyslexia. Annals of Dyslexia, 44, 147-164

Nicolson R. I., Fawcett A. J. (1995). Dyslexia is more than a phonological disability. Dyslexia, 1, $19-36$

Nicolson R. I., Fawcett A. J. (1999). Developmental Dyslexia: The Role of the Cerebellum. Dyslexia, $5,155-177$

Nicolson R. I., Fawcett A. J., Dean P. (1995). Time estimation deficits in developmental dyslexia: Evidence of cerebellar involvement. Proc. R Soc. Lond B Biol. Sci., 259, 43-47

Nicolson R. I., Fawcett A. J., Dean P. (2001). Developmental dyslexia: The cerebellar deficit hypothesis. Trends in Neurosciences, 24, 508-511

Ober J., Jaśkowska E., Jaśkowski P., Ober J. J. (1998). Presentation of the new method of testing development - reading function - word test and chain sentences test. Logopedia, 25, 81-99

Pennington B. F. (2008). Diagnosing Learning Disorders, Second Edition. A Neuropsychological Framework. New York: Guilford Press

Rack J. P., Snowling M. J., Hulme C., Gibbs S. (2007). No evidence that an exercise-based treatment programme (DDAT) has specific benefits for children with reading difficulties. Dyslexia, $13(2), 97-104$

Rae C., Lee M. A., Dixon R. M., Blamire A. M., Thompson C. H., Styles P., Talcott J., Richardson A. J., Stein J. F. (1998). Metabolic abnormalities in developmental dyslexia detected by magnetic resonance spectroscopy. The Lancet, 351, 1849-1852

Rae C., Harasty J. A., Dzendrowskyj T. E., Talcott J. B., Simpson J., Blamire A. M., Dixon R. M., Lee M. A., Thompson J. T., Styles P., Richardson A. J., Stein J. F. (2002). Cerebellar morphology in developmental dyslexia. Neuropsychologia, 40, 1285-1292

Reynolds D., Nicolson R. I. (2007). Follow-up of an exercise-based treatment for children with reading difficulties. Dyslexia, 13 (2), 78-96

Reynolds D., Nicolson R. I., Hambly H. (2003). Evaluation of an exercise-based treatment for children with reading difficulties. Dyslexia, 9 (3), 164-176

Schmahmann J. D. (2002). Disorders of the Cerebellum: Ataxia, Dysmetria of Thought, and the Cerebellar Cognitive Affective Syndrome. Neuropsychiatric Practice and Opinion, 16, 367-378

Shaywitz S. E. (1998). Dyslexia. New England Journal of Medicine, 338, 307-312

Shaywitz S. E., Shaywitz B. A., Fletcher J. M., Escobar M. D. (1990). Prevalence of reading disability in boys and girls: Results of the Connecticut longitudinal study. Journal of the American Medical Association, 264, 998-1002 
Silveri M. C., Misciagna S., Leggio M. G., Molinari M. (2000). Cerebellar spatial dysgraphia: Further evidence. J. Neurol., 246 (4), 312-313

Snowling M. J., Hulme C. (2003). A critique of claims from Reynolds, Nicolson \& Hambly (2003) that DDAT is an effective treatment for children with reading difficulties - 'Lies, damned lies and (inappropriate) statistics?' Dyslexia, 9 (2), 127-133

Stein J. (2004). Wielkokomórkowa teoria dysleksji rozwojowej. W: A. Grabowska, K. Rymarczyk (red.), Dysleksja od badań mózgu do praktyki (s. 43-75). Warszawa: Instytut Biologii Doświadczalnej im. M. Nenckiego PAN

Turkeltaub P. E., Eden G. F., Jones K. M., Zeffiro T. A. (2002). Meta-analysis of the functional neuroanatomy of single-word reading: Method and validation. Neuroimage, 16 (3), 765-780

\title{
PATRYCJA RUSIAK
}

\section{EFFECTIVENESS OF TREATMENT OF DEVELOPMENTAL DYSLEXIA ON THE BASIS OF THE THERAPEUTIC PROGRAM LEARNING BREAKTHROUGH}

\begin{abstract}
Developmental dyslexia is a disorder that involves reading and writing skills of young individuals. Numerous hypotheses have been proposed to explain its origins. One of them is the theory of cerebellar deficit, which assumes that the major factor impeding the process of learning to read and write is a dysfunction in anatomy and functioning of the cerebellum, which results in some deficits in the automation process.

For several years, there have been performed studies aimed at the construction of effective therapeutic tools. Yet, at present, convincing evidence for the effectiveness of these tools is lacking.

In the current study the effectiveness of the Learning Breakthrough therapeutic program was examined. There were used four reading tests to be done twice - before and after a 4-month training. An improvement on reading tests was expected in the experimental group only. However, no significant differences between pretests and posttests and between the experimental group and the control one, were observed. These findings suggest that the therapeutic intervention have not improved the level of reading in the dyslexics.
\end{abstract}

Keywords: developmental dyslexia, therapy, cerebellar deficits. 